\title{
GENUS DIPLASIOLEJEUNEA (LEJEUNEACEAE, PORELLALES) NEW TO INDIA, WITH RECORDS OF TWO SPECIES FROM THE WESTERN GHATS
}

\author{
V. K. Chandini ${ }^{1}$, T. Pócs ${ }^{2 *}$ and C. N. Manju ${ }^{1}$ \\ ${ }^{1}$ Department of Botany, the Zamorin's Guruvayurappan College \\ (affiliated to the University of Calicut), GA College P. O., Kozhikode, Kerala-673014, India; \\ E-mails:vkchandvk@gmail.com, manjucali@gmail.com \\ ${ }^{2}$ Department of Botany, Institute of Biology, Eszterházy University \\ H-3301 Eger, Pf. 43, Hungary; E-mail: pocs.tamas33@gmail.com, corresponding author
}

(Received: 3 March 2021; Accepted: 29 July 2021)

The genus Diplasiolejeunea is added to the liverwort flora of India from the Kerala part of the Western Ghats reporting two species: Diplasiolejeunea cavifolia Steph. and D. cobrensis Gottsche ex Steph. The genus is known from tropical Asia with eight species. Among them Diplasiolejeunea cavifolia is widespread, but still the genus was not yet recorded from India.

Key words: Diplasiolejeunea, genus record, India, Kerala, Lejeuneaceae, Western Ghats

\section{INTRODUCTION}

Diplasiolejeunea (Spruce) Schiffn. is a pantropical genus of the liverwort family Lejeuneaceae represented by approximately 75 valid species (Prudêncio et al. 2018, Söderström et al. 2016) around the world. Most of the species are epiphytes and occur in a good number in the American and African continents, but from Asia this genus is represented only by eight species including the pantropical Diplasiolejeunea cavifolia Steph., D. cobrensis Gottsche ex Steph. and D. rudolphiana Steph. while D. ingekarolae Schäf.-Verw., D. jovet-astiae Grolle, D. longilobula Herzog, D. onraedtii Grolle, and D. patelligera Herzog are restricted to Asia (Grolle 1995, He 1997, Lai et al. 2008, Piippo 1990, 1994, Schäfer-Verwimp 2004, 2006, Zhu and So 2001).

The genus Diplasiolejeunea is characterised by the development of underleaves along every lateral leaf (similar condition is found only in the genus of Colura (Dumort.) Dumort.). Leaf lobes are large, usually loosely imbricate, apices are broad and rounded, leaf cells of lobes plane or with distinct trigones and intermediate thickenings and often with ocelli, hyaline papilla is situated at the base of the tooth on the inner surface of the lobule, underleaves deeply bifid with sharp or blunt apices and the perianth is sharply five keeled. The species of the genus are epiphytes (epiphyllous or ramicolous, growing on living leaves or on twigs) in the wet tropics. 
During our recent investigation of the family Lejeuneaceae of Kerala, some interesting specimens were observed, among these two species belonging to the genus Diplasiolejeunea, viz. D. cavifolia and D. cobrensis. The majority of Diplasiolejeunea species are recorded from a narrow range of distribution, except for D. cavifolia, D. cobrensis and D. rudolphiana, which are pantropical (Dong et al. 2012). However, the present study recorded for the first time the genus along with these two species from India. A detailed description of both species with photo plates, illustration and the distribution map of $D$. cobrensis are provided.

\section{DESCRIPTION OF SPECIES}

\section{Diplasiolejeunea cavifolia Steph.}

(Figs 1-2)

Diplasiolejeunea cavifolia Steph., Bot. Jahrb. Syst. 20: 318 (1895); Piippo, Trop. Bryol. 9: 55 (1994); Schäfer-Verwimp, Cryptogamie, Bryol. 25(1): 13 (2004). - Bas.: Lejeunea cavifolia Steph., Bot. Jahrb. Syst. 8: 89 (1886). = Diplasiolejeunea brachyclada A. Evans, Bull. Torr. Bot. Club, 39: $216(1912) .=$ D. javanica Steph. Sp. Hepat. (Stephani) 5: $928(1916) .=$ D. ocellata Steph., Sp. Hepat. (Stephani) 5: 920 (1916). = D. vandenberghenii Grolle, Rev. Bryol. Lichénol. 29: 208 (1960), nom. illeg.

Diplasiolejeunea cavifolia was described by Stepani under different names as D. javanica Steph., D. ocellata Steph. and Lejeunea cavifolia Steph. (Blocked synonym Lejeunea cavifolia (Ehrh.) Lindb.; later homonym), many other workers also reported this species under different names. Unknowingly, Evans (1912) also reported this species as D. brachyclada Evans from Puerto Rico with detailed description and illustrations. Later, all these names were synonymised under Diplasiolejeunea cavifolia (Grolle 1978, Jones and Harrington 1983).

Plants pale green to yellowish, scattered, $4-8 \mathrm{~mm}$ long, $1.25-1.56 \mathrm{~mm}$ wide including leaves, stem widely branching; rhizoids hyaline, clustered at the base of underleaves. Leaves loosely imbricated, lobes widely spreading, not firmly appressed to the substratum, broadly ovate, plane, $0.75-1.0 \times$ $0.5-0.6 \mathrm{~mm}$, dorsal margin rounded and extending across the stem, slightly curved or with wavy margin, margin plane, apex rounded or slightly obtuse in some leaves. Cells plane, without trigones and intermediate thickenings, thick walled, marginal cells rectangular to polygonal, 9.2-15.3 × 10.2-16.6 $\mu \mathrm{m}$, median cells polygonal, $8.4-23.6 \mu \mathrm{m}$, basal cells elongated, polygonal, 15.8$35.5 \times 11.2-21.1 \mu \mathrm{m}$, ocelli scattered in the lobe; lobule ovate, $0.4-0.5 \times 0.2-0.28$ $\mathrm{mm}$, inflated, $1 / 2$ as long as the leaf lobe, keel arched, free margin involute up to near the base, first tooth acute (median), truncate or T-shaped, three to four cells long, one or two cells wide at base, proximal tooth inflexed, shorter than first tooth, lies along the ventral margin of leaf lobe, acute, hyaline papilla 
seen on the base of the first tooth, indistinct. Underleaves distant, rounded to subcordate at base, deeply bifid, $0.22-0.30 \times 0.18-0.20 \mathrm{~mm}$, three times wider than the stem, sinus wide, lobes 6-10 cells wide at base, acute, margin en-
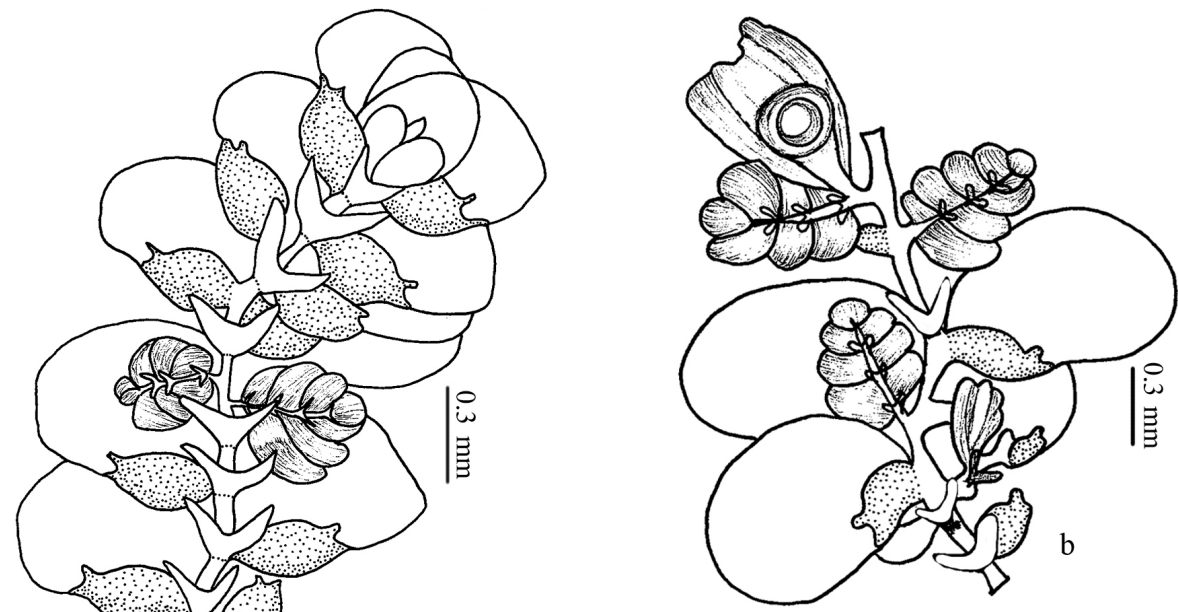

a
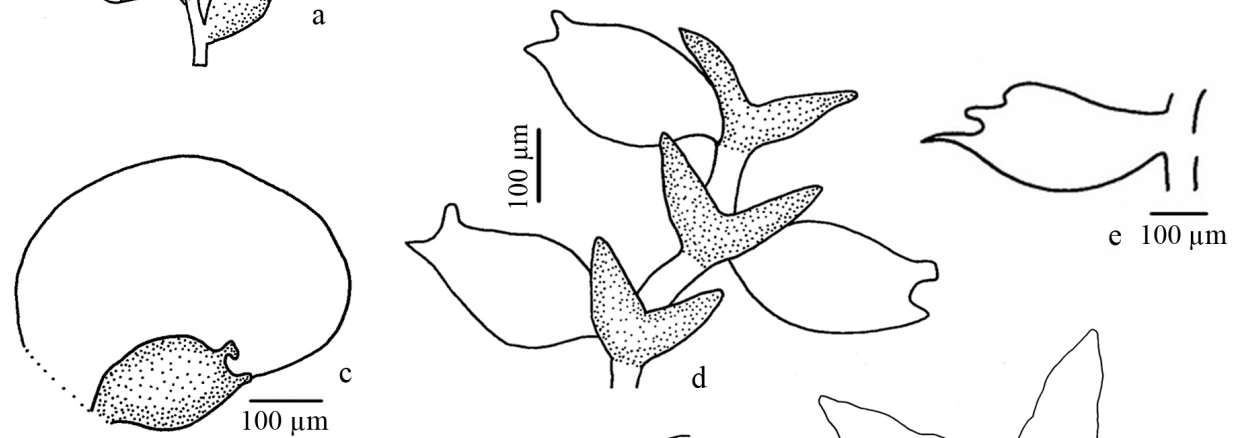

e $\overline{100 \mu \mathrm{m}}$
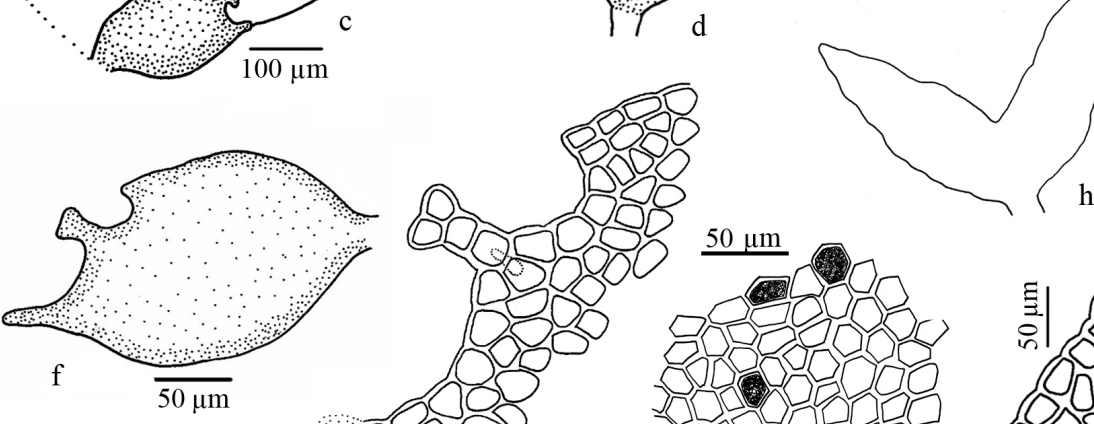

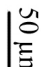
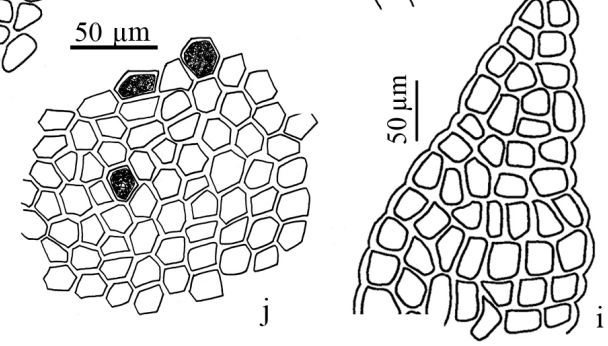

Fig. 1. Diplasiolejeunea cavifolia Steph. $\mathrm{a}=$ portion of plant with male branch; $\mathrm{b}=$ portion of plant with androecial and gynoecial branches; $c=$ single leaf with lobule; $d=$ plant ventral view with lobule and underleaf; $\mathrm{e}, \mathrm{f}=$ lobules; $\mathrm{g}=\mathrm{t}$-shaped lobule with basal hyaline papilla; $h=$ underleaf; $i=$ underleaf lobe cells; $j$ = leaf lobe cells (after Chandini 10515b) 


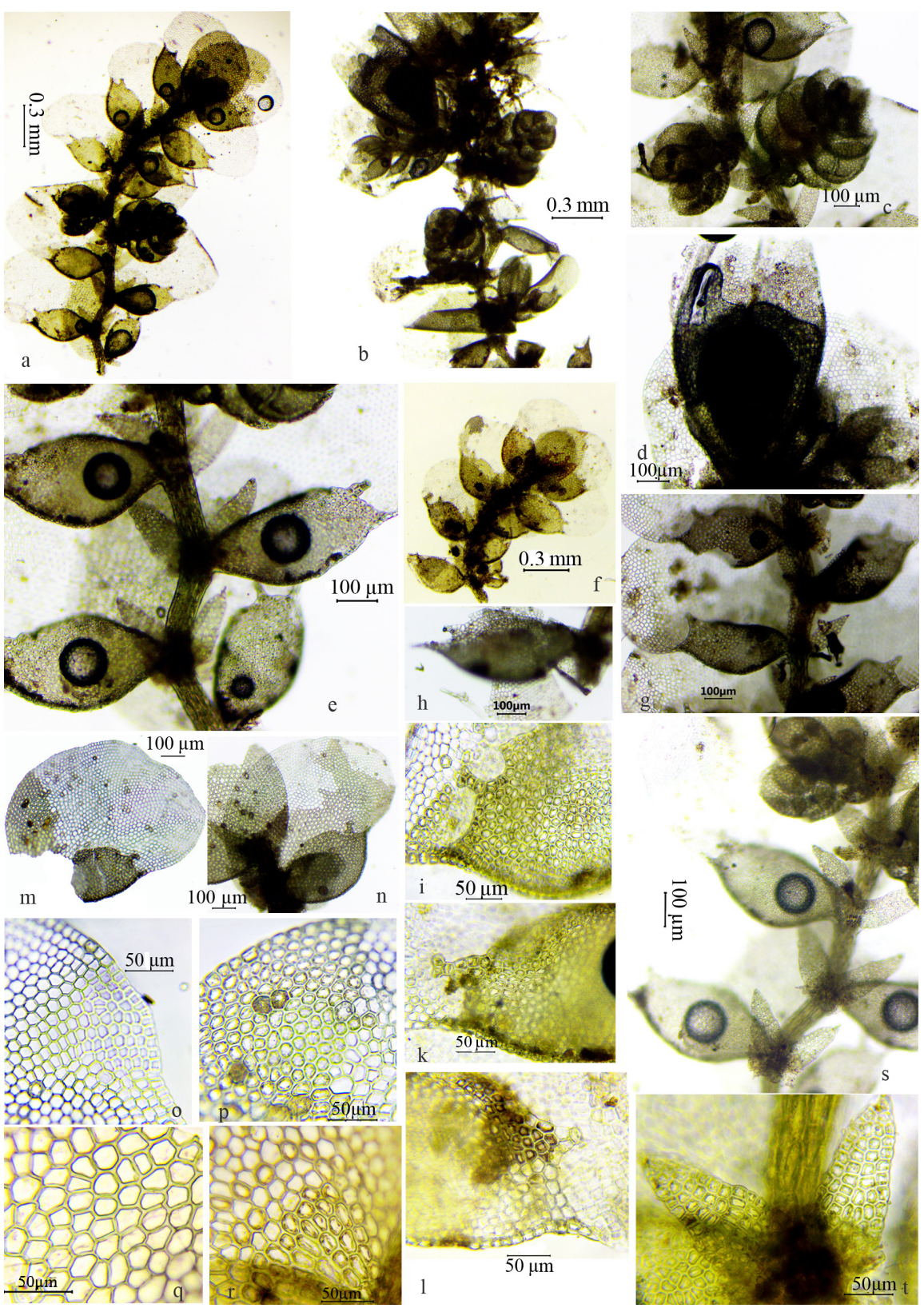

Fig. 2. Diplasiolejeunea cavifolia Steph. $\mathrm{a}=$ plant with male branch; $\mathrm{b}=$ portion of plant with male and female branch; $c=$ male branch; $d$ = perianth; e and $g=$ plant ventral view with lobule and underleaf; $f=$ portion of plant; $h, i, j, k, 1=$ different leaf lobules; $m, n=$ leaf lobe; $\mathrm{o}, \mathrm{p}=$ leaf lobe marginal cells; $\mathrm{q}=$ leaf lobe median cells; $\mathrm{r}=$ leaf lobe basal cells; $\mathrm{s}=$ portion of stem with underleaves; $\mathrm{t}$ = single underleaf lobule (after Chandini 10515b) 
tire. Monoecious, observed as autoicous, female inflorescence present on very short branch, perianth oblong or oblong ovate, rounded to truncate at apex, very short beak present, $0.76-0.12 \times 0.46-0.85 \mathrm{~mm}$, bracts obliquely spreading, rounded at apex, as long as leaf lobe; male gametoecia on very short branches, bracts imbricate, in 3-4 pairs, mature sporophyte is not seen by us (Figs 1 and 3). Spori, as observed by Weis (2001), are $45-55 \times 20-30 \mu \mathrm{m}$ in size, with rosettes of 5-7 $\mu \mathrm{m}$ diameter decorated by obtuse spines.

Specimen examined: India, Kerala, Palakkad district, Silent Valley National Park, Parathode, way to Poochippara (1,000 m +), coll.: Chandini (10515b), 11.01.2018 (ZGC).

Habitat: Epiphyllous, associated with Lejeunea cocoes Mitt., Leptolejeunea elliptica (Lehm. et Lindenb.) Schiffn. in evergreen forest above 1,000 m.

Distribution: Cambodia, China (Hainan), Java, Sumatra, Luzon, Malaysia, Sri Lanka, Taiwan, New Caledonia (Schäfer-Verwimp 2006), Vietnam, Laos and Thailand, Philippines (Lai et al. 2008, Miller et al. 1983, Söderström et al. 2020), Australia (McCarthy 2003), Melanesia (Piippo 1990), West Indies (Evans 1912, Reyes 1982, incl. distribution map), Central America, Mexico, South America (Schäfer-Verwimp 2004), all over tropical Africa (Wigginton 2018), Madagascar and the Mascarene islands (Marline et al. 2012, Wigginton 2018).

\section{Diplasiolejeunea cobrensis Gottsche ex Steph.}

(Figs 3-5)

Diplasiolejeunea cobrensis Gottsche ex Steph., Spec. Hepat. 5: 923 (1916) subsp. cobrensis = D. harpaphylla Steph., Sp. Hepat. 5: 919 (1916). = D. incurvata Jovet-Ast et Tixier, Rev. Bryol. Lichénol. 31: 29 (1962).

Plant small, light green, loosely attached to the substratum, 2-4 mm long, 0.85-1.1 mm wide including leaves, irregularly branched, branches up to 1 $\mathrm{mm}$ long, stem c.s. with 3 medullary and 7 cortical cells, $82.9 \mu \mathrm{m}$ in diameter; rhizoids hyaline, fasciculate. Leaves imbricate, obliquely spreading, lobe convex in dorsal margin, asymmetric, semi-circular, broadly ovate, $0.6-0.67$ $\times 0.48-0.60 \mathrm{~mm}$, ventral margin curved to nearly straight, entire, cells with prominent trigones and intermediate nodular thickenings, usually one per cell wall, marginal cells rectangular to pentagonal, $6.9-11.6 \times 8.2-15.4 \mu \mathrm{m}$, median cells polygonal, $13.2-25.6 \times 10-25.9 \mu \mathrm{m}$, basal cells more irregular, $20.8-$ $35.6 \mu \mathrm{m}$ in size; ocelli scattered, $8-15$, basal ocellus larger than companion cells, usually one, rarely two, $53.2-60.4 \times 30.2-37.5 \mu \mathrm{m}$; oil bodies $2-5$ per cells, rounded, granular, scattered in lobes, lobules and underleaves; lobules inflated, tubulate, $1 / 3-1 / 2$ as long as the leaf lobe, $0.17-0.19 \times 0.07-0.09 \mathrm{~mm}$, first tooth normally well developed, consisting of 1-2 cells, single cell observed 

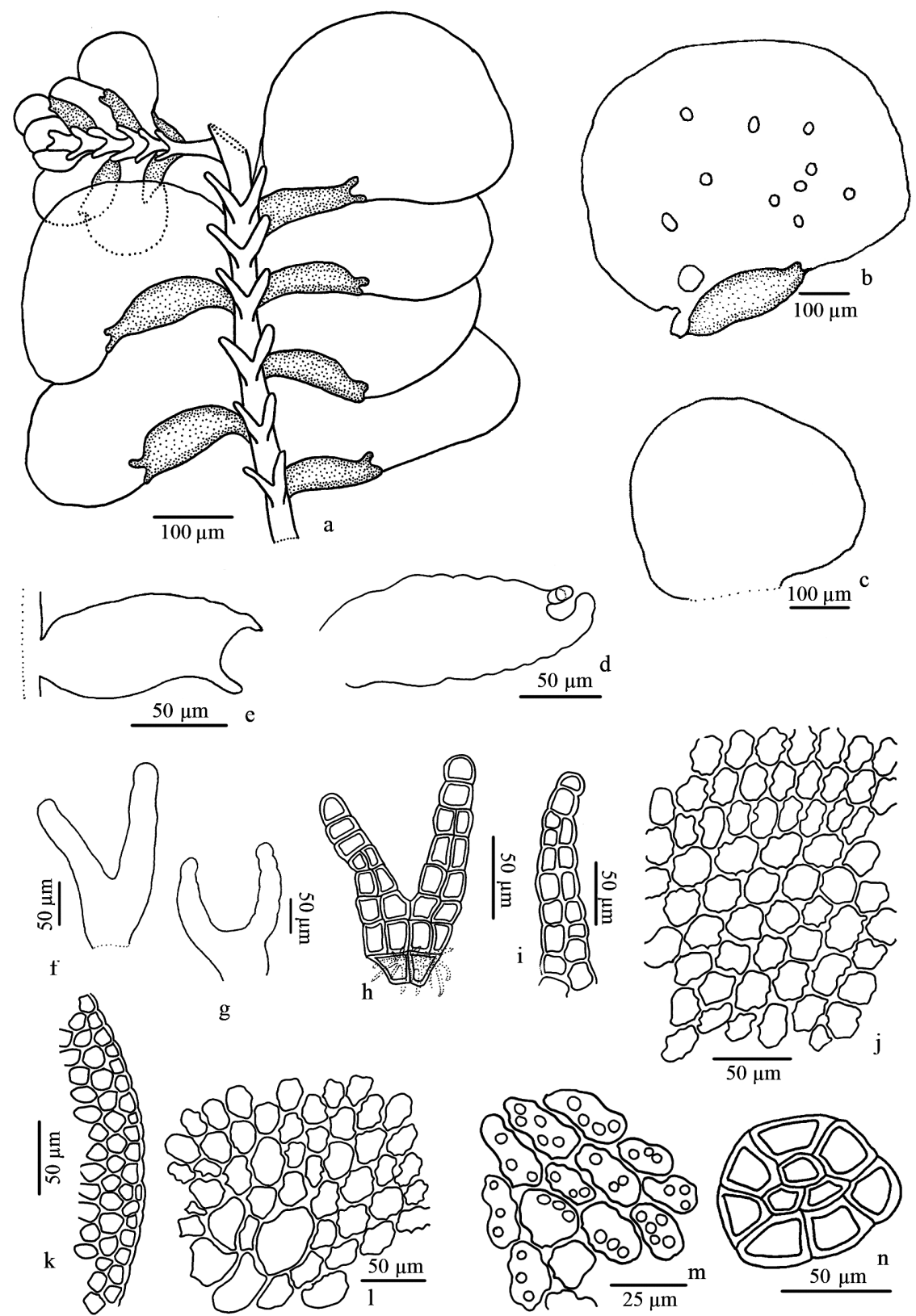

Fig. 3. Diplasiolejeunea cobrensis Gottsche ex Steph. $\mathrm{a}=$ portion of plant ventral view; $\mathrm{b}=$ single leaf (ventral); $\mathrm{c}=$ single leaf (dorsal); $\mathrm{d}$, e = leaf lobules; $\mathrm{f}, \mathrm{g}, \mathrm{h}=$ underleaves; $\mathrm{i}=\mathrm{un}$ derleaf lobe cells; $\mathrm{j}=$ leaf lobe median cells with trigones and intermediate thickenings; $\mathrm{k}=$ marginal cells; 1 = leaf lobe basal cells with ocelli; $\mathrm{m}=$ leaf cells with oil bodies; $\mathrm{n}=$ stem $\mathrm{c}$. s. (after Vinjusha 13182b) 

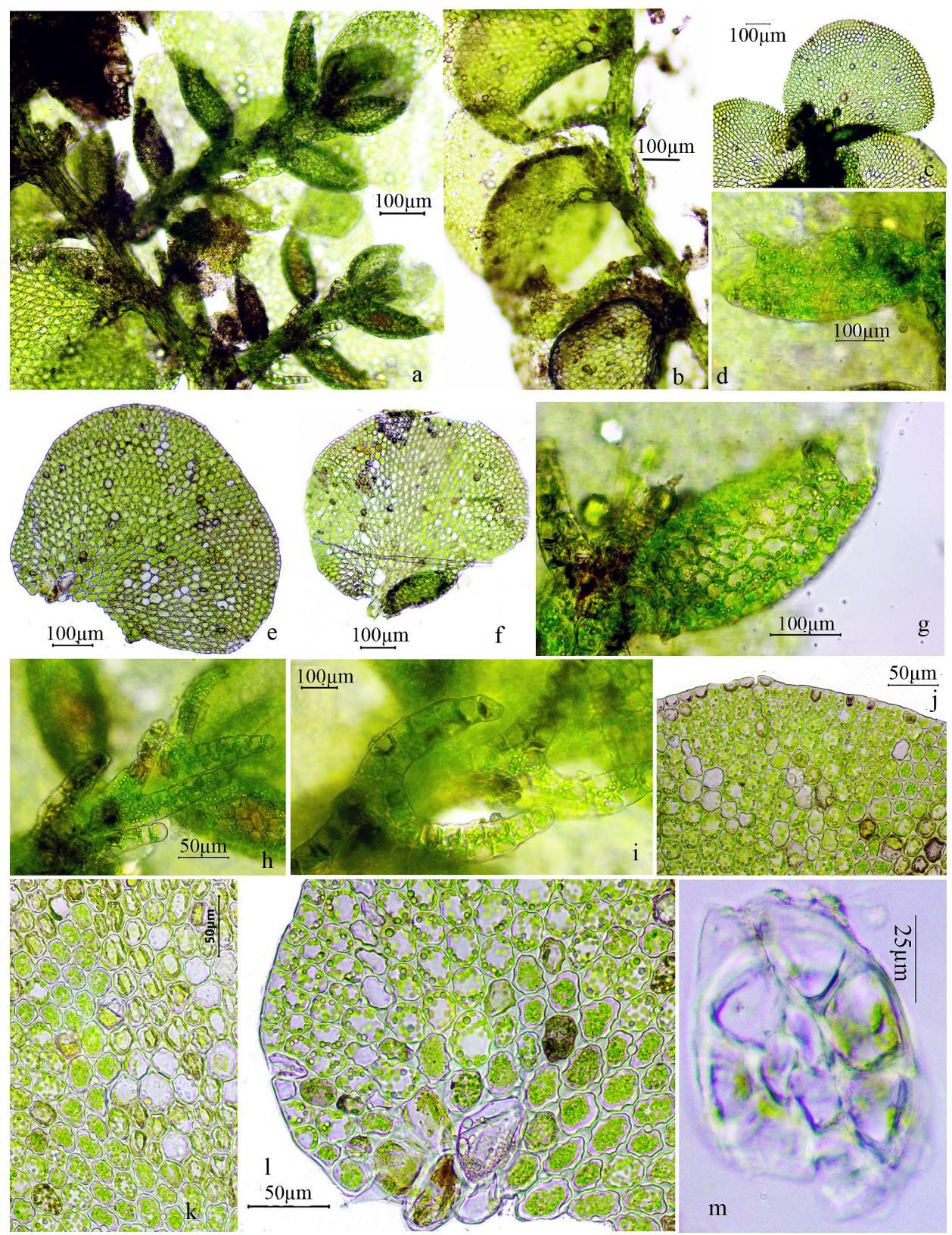

Fig. 4. Diplasiolejeunea cobrensis Gottsche ex Steph. $\mathrm{a}=$ portion of plant with branches; $\mathrm{b}=$ portion of plant, ventral view; $c=$ leaf arrangement on stem; $d, g=$ leaf lobule; $\mathrm{e}=$ leaf lobe; $\mathrm{f}=$ leaf with lobule; $\mathrm{h}, \mathrm{i}=$ underleaves; $\mathrm{j}=$ leaf lobe maginal cells; $\mathrm{k}=$ leaf lobe median cells; $1=$ leaf lobe basal cells with ocelli; $m$ = stem c. s. (after Vinjusha 13182b) 
as superimposed in some lobules, proximal tooth one celled, indistinct, lies along the ventral margin, hyaline papilla indistinct at base of lobule teeth. Underleaves small, not much wider than the stem, deeply bilobed nearly to the base, sinus U- or V-shaped, $0.12-0.22 \times 0.05-0.09 \mathrm{~mm}$, lobes $2-3$ cells wide at base; biseriate, 5-6 cells long, ending with 1-3 uniserial cells at tip, sexual and asexual reproductive structures not seen (Figs 2 and 4).

Habitat: Epiphyllous, associated with Leptolejeunea balansae Steph. in semi-evergreen forests.

Specimen examined: India, Kerala, Wayanad district, Kuruva dweep (750 m), approx. $11^{\circ} 49^{\prime} \mathrm{N}, 76^{\circ} 06^{\prime} \mathrm{E}$, coll.: Vinjusha (13182b), 07.12.2018 (ZGC).

Distribution: Cuba (type from El Cobre, coll.: Wright 1173) (Reyes 1982); Guyana (Gradstein and Hekking 1989); Brasil (Germano and Pôrto 2004, Prudêncio et al. 2018, Schäfer-Verwimp 1992); West Africa (Ghana - Jones 1973; Sierra Leone - Jones and Harrington 1983, East African islands (Mafia - Pócs and Váňa 2015; Mayotte - Pócs 2010; Madagascar - Grolle 1966, Tixier 1986 (several localities under D. harpaphylla); Pócs 2001 (also the ssp. nov. andringitrae); Dong et al. 2012, Marline et al. 2012), China (Hainan - Zhu and So 2001), Vietnam (Jovet-Ast and Tixier 1962 (as D. incurvata sp. nov.)); Thailand (Tixier 1973, 1986 (as D. incurvata), Schäfer-Verwimp 2006, Lai et al. 2008); Malaysia (Sabah, Mt Kinabalu - Mizutani 1966 (mistaken as D. brachyclada, corrected in 1970 and a Sabah east coast record added). There is an unpublished record new to the Andes: Peru, Dept. Pasco, prov. Oxapampa, Parque Nacional Yanachaga-Chemillén, epiphyllous in cloud forest at 2,415 m elevation. Coll. J. Larraín \& C. Rothfels (40272/AB), 22 May 2016, det. Pócs (EGR!).

\section{DISCUSSION}

Even though, Diplasiolejeunea cavifolia is described as widely distributed one, not yet reported any species of Diplasiolejeunea from India. This may be due to the inadequate survey of the family Lejeuneaceae in our area. Compared to other genera of Lejeuneaceae of Kerala Diplasiolejeunea are represented only with these collections. Both taxa are epiphyllous along with the other members of the same family and prefer montane evergreen forest patches. They are easily identifiable by its double number of underleaves and not firmly appressed nature of the thallus to the substratum. D. cavifolia is distinguished by its leaf lobules with mostly three to four cells long linear or T-shaped first tooth. Lobe cells plane and mostly hexagonal in shape, distant underleaves with triangular, acute lobes. $D$. cobrensis can be distinguished by half circle shaped lobes, its cells with trigones and intermediate nodular thick- 
enings, with $2-5$ oil bodies, scattered ocelli with large basal ones. The lobule is tubular with usually two celled first tooth and with an obsolete second tooth. Underleaves small and deeply bilobed nearly to the base with 2-3 basal cells, biseriate lobes ending at 2-3 celled uniseriate apex. $D$. cobrensis has similarities by its tubular lobule and small underleaves with 1-2 cells wide segment to Diplasiolejeunea cornuta Steph., widespread in Africa. But differs from it by its entire lobe margin and by its scattered ocelli $(D$. cornuta has acuminate lobes with dentate margin and only basal ocelli). It is remarkable, how different the two Indian species are in their way of dispersal. While D. cavifolia is very widespread and common in all wet tropics, D. cobrensis, although also pantropical, in general is very rare and has a scattered distribution (see map on Fig. 5). The explanation of this difference is not easy, as both are monoecious, have no organs of vegetative reproduction and rarely produce sporophytes. The spori of $D$. cavifolia are too large for long range air dispersal and the spori of $D$. cobrensis are not yet known. Either historical factors cause the difference or they are able to reproduce themselves at different level of fragmentation and so aerial dispersal can be counted to different extent. Dong et al. (2012) claimed on the base of their phylogram of maximum likelihood analysis, that $D$. cavifolia evolved in the Neotropis and from there dispersed to the Paleotropis and D. cobrensis, vice versa, evolved in Africa and migrated from there to the other continents.

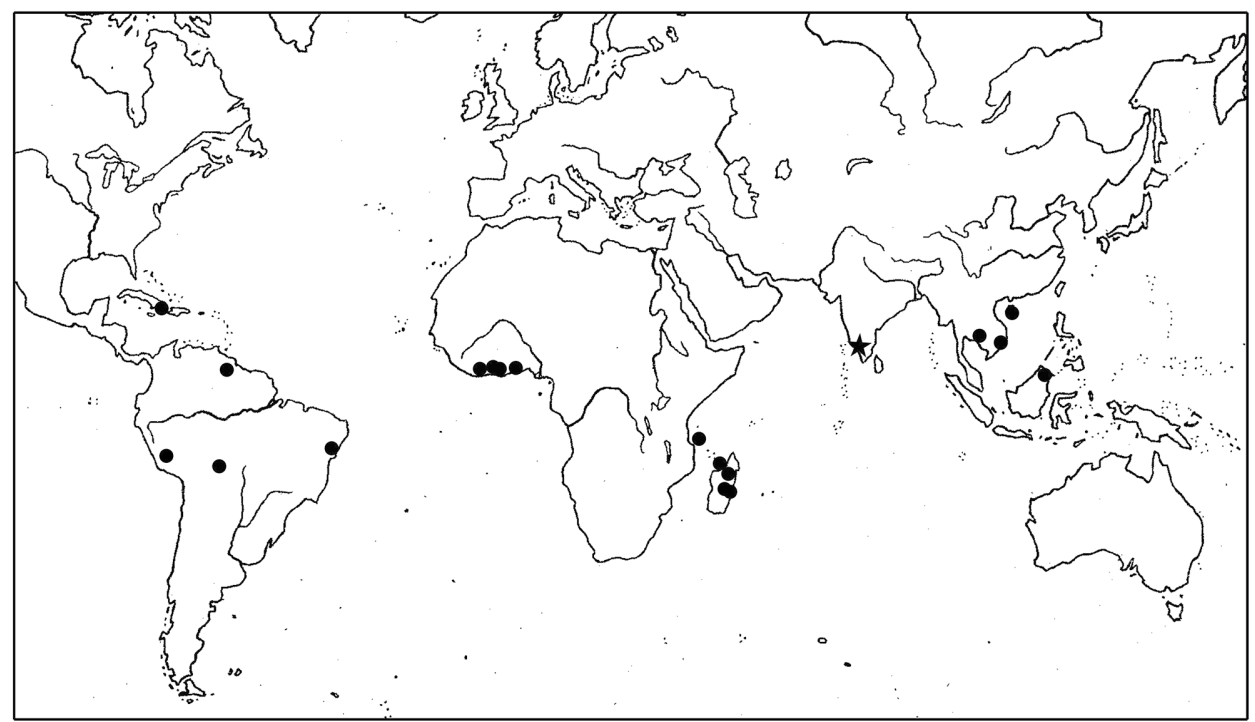

Fig. 5. Worldwide distribution of Diplasiolejeunea cobrensis Gottsche ex Steph. Dots = known distribution; asterisk = the new locality in India 
The present discovery is a new generic record for the Indian flora. Over the years several partial treatment and floristical approaches appeared, but a comprehensive world treatment of this genus was not yet published.

Acknowledgements - The authors are thankful to the authorities of the Zamorin's Guruvayurappan College for providing facilities and encouragement. The financial assistance from Kerala State Council for Science Technology and Environment (KSCSTE), Thiruvananthapuram is also acknowledged. We sincerely acknowledge the help rendered by the officials of Kerala Forest department for providing permission to collect bryophyte specimens from the study area.

\section{REFERENCES}

Dong, S., Schäfer-Verwimp, A., Meinecke, P., Feldberg, K., Bombosch, A., Pócs, T., Schmidt, A. R., Reitner, J., Schneider, H. and Heinrichs, J. (2012): Tramps, narrow endemics and morphologically cryptic species in the epiphyllous liverwort Diplasiolejeunea. Mol. Phyl. Evol. 65(2): 582-594. https://doi.org/10.1016/j.ympev.2012.07.009

Evans, A. W. (1912): Hepaticae of Puerto Rico. XI. Diplasiolejeunea. - Bull. Torrey Bot. Club 39(5): 209-225. https://doi.org/10.2307/2479376

Germano, S. R. and Pôrto, K. C. (2004): Novos registros de briófitas para Pernambuco, Brasil. - Acta Bot. Bras. 18(2): 343-350. https://doi.org/10.1590/s0102-33062004000200013

Gradstein, S. R. and Hekking, W. H. A. (1989): A catalogue of the bryophytes of the Guyanas. I. Hepaticae and Anthocerotae. - J. Hattori Bot. Lab. 66: 197-230.

Grolle, R. (1966): Über Diplasiolejeunea in Asien. - Feddes Repert. 73: 78-89. https://doi. org/10.1002/fedr.19660730203

Grolle, R. (1978): Eine neue Diplasiolejeunea-Art aus Sri Lanka. - Feddes Repert. 89: 301-305. https://doi.org/10.1002/fedr.4910890502

Grolle, R. (1995): The Hepaticae and Anthocerotae of the East African Islands. An annotated catalogue. - Bryophyt. Bibl. 48: 1-178.

He, X.-L. (1997): A review and checklist of the Lejeuneaceae in China. - Abstracta Bot. 21: 69-77.

Jones, E. W. (1973): African Hepatics XXIV. Lejeuneaceae: some new or little-known species, and extensions of range. - J. Bryol. 7: 545-561. https://doi.org/10.1179/jbr.1973.7.4.545

Jones, E. W. and Harrington, A. J. (1983): The hepatics of Sierra Leone and Ghana. - Bull. Brit. Mus. (Nat. Hist.), Bot. 11(3): 215-289.

Jovet-Ast, S. and Tixier, P. (1962): Hepatiques du Viet-Nam, II. - Rev. Bryol. Lichénol. 31(12): 23-33.

Lai, M.-J., Zhu, R.-L. and Chantanaorrapint, S. (2008): Liverworts and hornworts of Thailand: an updated checklist and bryofloristic accounts. - Ann. Bot. Fenn. 45: 321-341. https://doi.org/10.5735/085.045.0501

Marline, L., Andriamiarisoa, R. L., Bardat, J., Chuah-Petiot, M., Hedderson, T. A., Reeb, C., Strasberg, D., Wilding, N. and Ah-Peng, C. (2012): Checklist of the bryophytes of Madagascar. - Cryptogamie, Bryol. 33(3): 199-255. https://doi.org/10.7872/cryb.v33. iss3.2012.199 
McCarthy, P. M. (2003): Catalogue of Australian liverworts and hornworts. - Flora of Australia, Suppl. Series 21. Australian Biological Resources Study, Canberra, 137 pp.

Miller, H. A., Whittier, H. O. and Whittier, B. A. (1983): Prodromus Florae Hepaticarum Polynesiae. - Bryophyt. Bibl. 25: 1-423.

Mizutani, M. (1966): Epiphyllous species of Lejeuneaceae from Sabah (North Borneo). - J. Hattori Bot. Lab. 29: 153-170.

Mizutani, M. (1970): Lejeuneaceae, subfamilies Lejeuneoideae and Cololejeuneoideae from Sabah (North Borneo). - J. Hattori Bot. Lab. 33: 225-265.

Piippo, S. (1990): Annotated catalogue of Chinese Hepaticae and Anthocerotae. - J. Hattori Bot. Lab. 68: 1-192.

Piippo, S. (1994): On the bryogeography and ecology of Western Melanesian Lejeuneaceae, with comments on their epiphyllous occurrence. - Trop. Bryol. 9: 43-57.

Pócs, T. (2001): East African Bryophytes, XVI. New taxa of Lejeuneoideae (Lejeuneaceae) collected by Patricia Geissler in Manongarivo Special Reserve, NW Madagascar. Candollea 56(1): 69-78.

Pócs, T. (2010): East African Bryophytes, XXVI. New records from Mayotte (Maore) Island (French Comoro). - Acta Bryolichenol. Asiatica 3: 105-114.

Pócs, T. and Váňa, J. (2015): East African Bryophytes XXX. New liverwort and hornwort records. - Acta Biol. Plant. Agriensis 3: 3-21.

Prudêncio, R. X. A., de Mello, Z. R. and da Costa, D. P. (2018): A new species of Diplasiolejeunea (Lejeuneaceae, Marchantiophyta) from Brazil. - Phytotaxa 385(1): 51-54. https://doi.org/10.11646/phytotaxa.385.1.8

Reyes, D. M. (1982): El genero Diplasiolejeunea en Cuba. - Acta Bot. Acad. Sci. Hung. 28(12): $145-180$.

Schäfer-Verwimp, A. (1992): New or interesting records of Brazilian bryophytes, III. - J. Hattori Bot. Lab. 71: 55-68.

Schäfer-Verwimp, A. (2004): The genus Diplasiolejeunea (Lejeuneaceae, Marchantiospida) in the Tropical Andes, with description of two new species. - Cryptogamie Bryol., 25(1): 3-17.

Schäfer-Verwimp, A. (2006): A new species of Diplasiolejeunea (Lejeuneaceae, Jungermanniopsida) from Sumatra, and a key for the genus in Asia. - Herzogia 19: 239-244.

Söderström, L., Hagborg, A., Pócs, T. and von Konrat, M. (2020): Listing the unknown, checklist of liverworts and hornworts of Laos. - Bryoph. Div. Evol. 42(1): 19-31. https://doi.org/10.11646/bde.42.1.2

Söderström, L., Hagborg, A., von Konrat, M., Bartholomew-Began, S., Bell, D., Briscoe, L., Brown, E., Cargill, D. C., Costa, D. P., Crandall-Stotler, B. J., Cooper, E. D., Dauphin, G., Engel, J. J., Feldberg, K., Glenny, D., Gradstein, S. R., He, X., Heinrichs, J., Hentschel, J., Ilkiu-Borges, A. L., Katagiri, T., Konstantinova, N. A., Larraín, J., Long, D. G., Nebel, M., Pócs, T., Puche, F., Reiner-Drehwald, E., Renner, M. A. M., Sass-Gyarmati, A., Schäfer-Verwimp, A., Segarra-Moragues, J. G., Stotler, R. E., Sukkharak, P., Thiers, B. M., Uribe, J., Váňa, J., Villarreal, J. C., Wigginton, M., Zhang, L. and Zhu, R.-L. (2016): World checklist of hornworts and liverworts. - PhytoKeys 59: 1-828. https://doi.org/10.3897/phytokeys.59.6261

Tixier, P. (1973): Bryophytae Indosinicae. Liverworts collected in Thailand. - Nat. Hist. Bull. Siam Soc. 24: 449-456.

Tixier, P. (1986): La notion d'espèce dans le genre Diplasiolejeunea. 3. Diplasiolejeunea harpahylla Steph., espèce palaeotropicale. - Cryptogamie, Bryol. Lichénol. 7(2): 141-147. 
Weis, G. (2001): Morphologische und anatomische Untersuchungen der Sporophyten bei den Jubulaceae Klinggr. und Lejeuneaceae Casares-Gil (Hepaticae) und deren systematische Bedeutung. - Bryoph. Bibl. 57: 1-302.

Wigginton, M. J. (2018): Checklist and distribution of the liverworts and hornworts of subSaharan Africa, including the East African Islands. - Trop. Bryol. Res. Reports 9: 1-138.

Zhu, R.-L. and So, M. L. (2001): Epiphyllous liverworts of China. - Nova Hedwigia Beih. 121: $1-418$.

Open Access statement. This is an open-access article distributed under the terms of the Creative Commons Attribution 4.0 International License (https://creativecommons.org/ licenses/by/4.0/), which permits unrestricted use, distribution, and reproduction in any medium, provided the original author and source are credited, a link to the CC License is provided, and changes - if any - are indicated. (SID_1) 